\title{
THE EFFECT OF AGRIBUSINESS SYSTEM APPLICATION TOWARDS SEAWEED FARMERS' INCOME: A CASE STUDY IN PAHUNGA LODU DISTRICT OF EAST SUMBA REGENCY, INDONESIA
}

\author{
Waluwanja Aldoni Riwan*, Prasetyo Edy, Setiadi Agus \\ Faculty of Animal and Agricultural Science, University of Diponegoro, Indonesia \\ *E-mail: riwansumba@gmail.com
}

\begin{abstract}
The application of the agribusiness system in the management of seaweed business is a factor that determines the success of seaweed business. The purposes of this research: identifying the level of application of agribusiness systems in seaweed farming; analyzing the effect of the application of agribusiness systems on the income of seaweed farmers. This research was conducted in Pahunga Lodu Subdistrict, East Sumba Regency, East Nusa Tenggara. The methods used in this study are qualitative (descriptive) and quantitative. Qualitative Descriptive Analysis is used to identify the level of the application of agribusiness systems in seaweed farming. Quantitative analysis with path analysis is used to analyze the effect of the application of agribusiness systems, namely the upstream sub-system, on farm sub-system, harvest and post-harvest sub-system, and marketing sub-system on the amount of production and its impact on the seaweed farmers' income. The results showed that the application of the agribusiness system in the upstream agribusiness sub-system, the on farm agribusiness sub-system and the harvesting and post-harvest agribusiness sub-systems were carried out very well, while the marketing agribusiness sub-system had not been done well. Upstream agribusiness sub-system, harvest and post-harvest agribusiness have a significant effect on the amount of production, while the on farm agribusiness sub-system does not significantly affect the amount of production. The marketing agribusiness subsystem and the amount of production have a significant effect on the income of seaweed farmers.
\end{abstract}

\section{KEY WORDS}

Agribusiness system, seaweed farming, production, farmers' income.

Agribusiness is a new way of seeing agriculture which was carried out sectorally and now it is done intersectionally; or if it was conducted using subsystem, now it's done using system. Agribusiness system covers 4 things, namely; 1). Upstream agribusiness system that produces production facilities; 2). On farm agribusiness system; 3). Downstream agribusiness system, that concerns processing activities and 4) Trading agribusiness system or product marketing. The four elements of the agribusiness system are closely related and integrated in the system (Saragih, 2007).

East Sumba Regency is in the administrative area of East Nusa Tenggara, which is a large producer of Eucheuma cottonii seaweed. The data collected from the Department of Marine and Fisheries of East Sumba (2016), the area of East Sumba which has the potential to be used as seaweed cultivation area is 5,800 ha, but until 2015 the area used for seaweed cultivation is only 347.1 ha $(5.79 \%)$ of the total potential land area, around $5,452.9$ ha of land resources have not been managed yet. In 2015, East Sumba was able to produce 4,524 tons of seaweed with a population of 2,816 people who cultivated seaweed.

The application of agribusiness systems in Pahunga Lodu District has not been able to be implemented properly, it can be seen that there are still a lot of seaweed farmers who face several problems such as:

1. Seaweed production in the farm level for the last 5 years has decreased as a result of the inability of the seaweed farmers to provide good quality production facilities. Seaweed seeds used by farmers are taken from their own production in the previous planting period continuously, thus it causes the quality of the seaweed seeds to 
decrease. The nylon rope used has been relatively old, so the rope is easily broken and there are only a number of the farmers who own nylon rope. In addition, many seaweed farmers do not have canoes, so that farmers are having difficulties in planting, maintaining and harvesting the seaweed. These problems are in line with the research done by Wantasen A. S and Tamrin (2012), where seaweed production in Nain Island has decreased due to the repetition use of seeds, so that the seeds have low quality because they carry seedlings that causes the seed endurance reduced. The results of the same study were also carried out by Aluman, et al, (2016), the low seaweed production in Bulagi District, Banggai Regency due to the limitations of the production factors owned by farmers. The limitation of production factors is the limited use of production inputs such as seeds, labour and the number of ropes used to tie seaweed. Sulaeman S's (2006) research results show that the obstacle for seaweed farmers in the production facilitiesare the availability of canoe boats used for treatment, transportation and harvesting.

- The quality of seaweed produced by farmers is low. Access to technology at the farmer level is very inadequate, seaweed farmers still use traditional post-harvest technology that is in the process of drying seaweed. This is related with the results of research by Hasiru et al (2010), some of the problems faced by seaweed farmers in North Gorontalo District are at the farm level, the problems faced arethe poor level of knowledge in cultivation, lack of good quality seeds, poor drying process seaweed and markets that still depend on collecting traders. While at the level of processing, the problem faced is the availability of dried seaweed as a raw material which is not in accordance with the needs, the bad quality of dried seaweed, and there are still a lot of dirt and foreign objects in it.

- Market information regarding the marketing of seaweed at the farm level is still very inadequate and farmer's dependence is very high on small collectors or middlemen who are around the farmer's environment as the main buyers of seaweed products. This is related with the results of Avrianti et al (2014) research, Seaweed farmers in Wuakerong Village do not have clear information related to marketing of seaweed. As a result farmers do not take part in determining the selling price of seaweed. Farmers are only recipients of prices, but are not price determinants.

The study of the application of agribusiness systems on seaweed farming, has not received much attention. So far, studies on seaweed commodities have only focused on the secular part of seaweed cultivation activities or research studies have not been conducted on the whole of seaweed cultivation activities, starting from upstream activities providing advice on production, cultivation, harvest and post-harvest as well as marketing activities. Most of the seaweed cultivation research only focused on the analysis of production and income, cultivation and marketing of seaweed. Therefore, research is needed on the effect of the application of agribusiness systems on the income of seaweed farmers in Pahunga Lodu District, Sumba Tmur District.

\section{METHODS OF RESEARCH}

This research was conducted in Pahunga Lodu District, East Sumba Regency. Location determination was carried out purposively or done intentionally with consideration that the area was the centre of seaweed cultivation in East Sumba Regency. The number of samples studied was 100 samples. Sample population determination is done by simple random sampling technique. Data collection techniques were carried out through a direct interview process with seaweed farmers using structured questionnaires. To facilitate the respondent in answering the question, an answer is provided with a Likert scale consisting of 4 points. Respondents were asked to give responses to the questions posed with an answer score of 1-4, that are: very good (4), good (3), bad (2), and very bad (1).

Data analysis methods used are qualitative (descriptive) and quantitative methods. Qualitative descriptive analysis was used to describe the level of application of seaweed agribusiness systems in Pahunga Lodu District, East Sumba Regency. To describe the level 
of application of seaweed agribusiness systems, it used a scoring index analysis technique to describe the respondents' perceptions of the question items. The calculation of the respondent's answer is done by the following formula:

$$
\begin{gathered}
\text { Index value }(\%)=\text { Total Score } / Y(\text { maximum score value }) \times 100 \\
\text { Interval value }=100 / \text { total score }(\text { Likert scale })=100 / 4=25
\end{gathered}
$$

Based on the interval value, the interpretation criteria are:

- $1 \%-25 \%=$ Poor;

- $26 \%-50 \%=$ Medium Poor;

- $51 \%-75 \%=$ Fair;

- $76 \%-100 \%$ = Very Good.

Quantitative analysis is used to analyze the effect of the implementation of agribusiness systems on the amount of seaweed production and the income of seaweed farmers.in this study, the writer used path analysis method with tetra IV software. The formula of path analysis is:

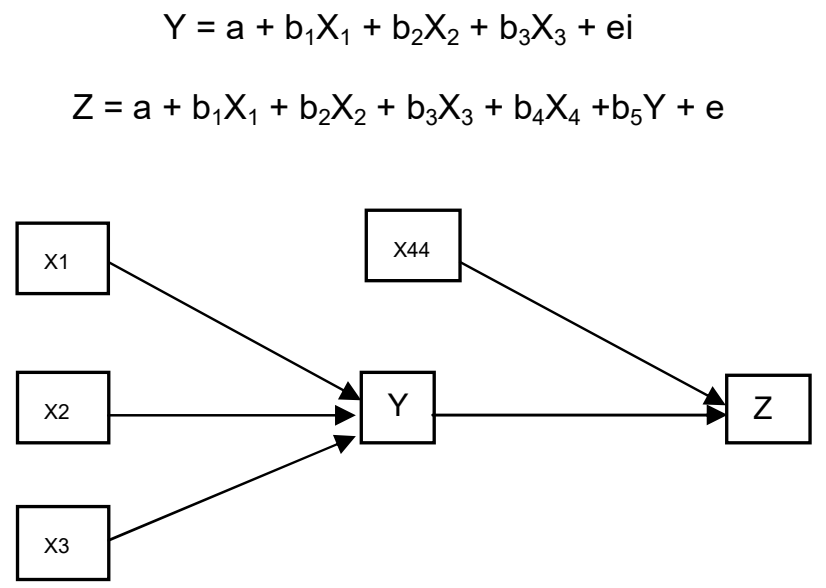

Figure 1 - Equation model of path analysis

Notes: $\mathrm{X} 1$ = the upstream agricultural sub-system, or provision of production facilities (Score); $\mathrm{X} 2$ = the on farm agribusiness sub-system (Score); $X 3=$ the harvest and post-harvest agribusiness sub-system (Score); $X 4$ = the marketing agribusiness sub-system (Score); $Y=$ the amount of seaweed production $(\mathrm{Kg}) ; \mathrm{Z}=$ the income of seaweed farmers $(\mathrm{Rp})$.

\section{RESULTS AND DISCUSSION}

The application of agribusiness system in seaweed farming in Pahunga Lodu District, East Sumba Regency is divided into 4 sub-systems, namely the upstream agricultural subsystem, the on farm agribusiness sub-system, the harvest and post-harvest agribusiness sub-system, and the marketing agribusiness sub-system (Table 1).

The upstream agribusiness subsystem related to the provision of production facilities such as seaweed seeds, nylon rope and canoes. Based on the results of the analysis in Table 1, the level of application of the upstream agribusiness subsystem is in a very good category with an index value of 86.8. It means that seaweed farmers are able to provide production facilities such as seeds, nylon rope and canoes in the best quantities and quality.

According to the Ministry of Marine Affairs and Fisheries Republic Indonesia (2005), a good seaweed seeds must have a large thallus, the pigmentation is above $70 \%$, green, not slimy and cannot get dirt in more than $5 \%$. The results of the analysis in Table 1 show that the index value for seaweed seeds quality is in a very good. It is because the number of index value shows of 90.0. Moreover, Nylon rope is also one of good products which havea very good quality. It can be used as a container or place to tie seaweed seeds. The Table 1 shows that the index value of nylon rope is 86.5 . Furthermore, canoe is also very important 
for seaweed farmers in supporting farmers in carrying out the process of cultivation, maintenance and harvesting of seaweed. The index value for canoe capacity is in the very good category with a value of 84.00 .

Table 1 - Distribution of Respondents and the Average number of Index Value in the Agribusiness System

\begin{tabular}{|c|c|c|c|c|c|}
\hline \multicolumn{6}{|c|}{ Application of Agribusiness Systems } \\
\hline \multirow{2}{*}{ Category } & \multicolumn{4}{|c|}{ Skor } & \multirow[t]{2}{*}{ Index Value } \\
\hline & 1 & 2 & 3 & 4 & \\
\hline \multicolumn{6}{|c|}{ Sub system of upstream agribusiness or provision of production facilities } \\
\hline Seaweed Seeds & 0 & 0 & 40 & 60 & 90 \\
\hline Nylon Rope & 0 & 3 & 48 & 49 & 86,5 \\
\hline Canoe & 3 & 6 & 43 & 48 & 84 \\
\hline Average & & & & & 86,8 \\
\hline \multicolumn{6}{|c|}{ On farm of agribusiness systems } \\
\hline Weather and Time Conditions Planting & 0 & 0 & 41 & 49 & 79,7 \\
\hline Seaweed Maintenance Intensity & 0 & 6 & 17 & 77 & 92,7 \\
\hline Average & & & & & 86,2 \\
\hline \multicolumn{6}{|c|}{ Pra- and post-harvest agribusiness systems } \\
\hline Seaweed Age & 0 & 0 & 36 & 64 & 91 \\
\hline Post Harvest Technology & 0 & 6 & 33 & 61 & 88,7 \\
\hline Average & & & & & 89,85 \\
\hline \multicolumn{6}{|c|}{ Marketing Agribusiness Sub system } \\
\hline Market or Customer & 32 & 45 & 15 & 8 & 49,75 \\
\hline Seaweed Price & 35 & 43 & 14 & 8 & 48,75 \\
\hline The average index is & & & & & 49,25 \\
\hline
\end{tabular}

Source: Primary data (2016).

Note: 4 = very good, $3=$ good, $2=$ bad and $1=$ very bad.

The on farm agribusiness subsystem is related to maintenance techniques during the cultivation period which include planting and maintenance activities. Table 1 show the level of application of on farm agribusiness sub-systems are in very good category with an index value of 86.2. It means that seaweed farmers are able to implement agribusiness subsystem very well. The success of seaweed's farmers in implementing the on farm agribusiness subsystem is due to the factor of farmers' knowledge about seaweed cultivation which is getting better, through a long experience process owned by farmers.

Time and weather conditions during the cultivation process directly affect the quality of the seeds that are cultivated. The analysis results in Table 1 show the time and weather conditions during the cultivation are in very good category with an index value of 79,7 .

Conservancy of seaweed is the most important activity that determines the success of seaweed cultivation. The analysis results in Table 1 show the intensity of seaweed conservancy in very good category with an index value of 92,7.

In the harvest and post-harvest agribusiness subsystem, the activities observed are harvesting and drying. Based on the analysis results in Table 1, the level of application of harvest and post-harvest agribusiness subsystem is in the very good category with an index value of 89,85 . This shows that seaweed farmers are able to apply the harvest and postharvest sub-systems very well.

According to Asriany (2014), harvesting time depends on its purpose, if the purpose is to get the seedlings, hence harvesting is done at the age of 25-30 days, whereas if the purpose is for the production with high susceptibility value, hence harvesting is done at the age of 45 days. The analysis results in Table 1 show that the seaweed harvesting age is in very good category with an index value of 91,00 . Seaweed farmers in Pahunga Lodu district, East Sumba, cultivate seaweed with the aim of being sold to the market not to produce seeds. Therefore, seaweed harvesting is carried out at the age of 40-45 days.

Post-harvest technology or the process of drying is one of the factors that will determine the quality of seaweed produced. The analysis results in Table 1 show that the seaweed drying technology is in very good category with an index value of 88,7 . This means, 
most seaweed farmers use post-harvest technology, in this case technology for seaweed processing, with very good quality.

According to Soekartawi (2002), marketing is a system of business activities which is intended to plan and determine prices, promote, and distribute goods and services that satisfy the needs of existing buyers and potential buyers, it also does not end at the time of selling or transaction.

Based on the analysis results in Table 1, the level of application of marketing agribusiness sub-systems is in bad category with an index value of 49,25 . This means that seaweed farmers have not been able to implement agribusiness marketing sub-system of seaweed products well. Seaweed farmers in marketing their products depend on the traders. Seaweed farmers do not have sufficient market information, so that it is causing farmers to not be able to control the market or market controlled by the wholesalers.

Following are the results of hypothesis analysis using path analysis methods (part analysis) can be seen in Table 2 below.

Table 2 - Hypothesis Testing (Part Analysis)

\begin{tabular}{llcccc}
\hline From & To & Coefficient (B) & T & Sig P & Explanation \\
\hline $\mathrm{X}_{1}$ & $\mathrm{Y}$ & 174,4045 & 3,5460 & 0,0006 & Have a significant effect \\
$\mathrm{X}_{2}$ & $\mathrm{Y}$ & 101,6779 & 1,7860 & 0,0772 & No significant effect \\
$\mathrm{X}_{3}$ & $\mathrm{Y}$ & 443,6864 & 9,9000 & 0.0000 & Have a significant effect \\
$\mathrm{X}_{4}$ & $\mathrm{Z}$ & 27619,7265 & 423,0449 & 0,0000 & Have a significant effect \\
$\mathrm{Y}$ & $\mathrm{Z}$ & 8631,9572 & 383,9281 & 0,0000 & Have a significant effect \\
\hline
\end{tabular}

Source: Primary data (2016).

Based on the results above, the path analysis or part analysis can be drawn as follows:

$$
\begin{gathered}
Y=174,4045 X 1+101,6709 X 2+443,6864 X 3+e \\
Z=174,4045 X 1+101,6709 X 2+443,6864 X 3+27619,7256 X 4+8631,9572 Y+e
\end{gathered}
$$

The Effect of the Application of Upstream Agribusiness Sub-system (X1) towards Total Production $(Y)$. The analysis results in Table 2 , the variable upstream agribusiness subsystem (X1) has a significant effect on the variable amount of seaweed production (Y). The variable upstream agribusiness subsystem $(X 1)$ has a significance value $|p| 0,0006$ smaller than 0,05 . The results of this analysis indicate that the better the level of the application of upstream agribusiness sub-system, in this case the provision of quality production advice, it will cause the greater the average number of seaweed production. The results of this study are in line with the research conducted by Akbar (2014), that capital production facilities have a significant effect on the amount of seaweed production in district Jeneponto.

The Effect of the Application of On Farm Agribusiness Sub-system (X2) towards Production Amount $(Y)$. The analysis results in Table 2, variable cultivation agribusiness system (X2) does not significantly affect the amount of seaweed production (Y). The cultivation agribusiness system variable $(X 2)$ has a significance value of $|p| 0,0772$ greater than 0,05 .

The main causes of on farm agribusiness systems that have no effect on the amount of production because seaweed is a commodity whose growth depends heavily on weather or climate conditions. Natural conditions that are good for the growth of seaweed, among others, have strong ocean currents, sea water in clear conditions and get high sunlight. The results of this study are in line with research conducted by Wuryaningsing, et al, (2014), which stated that weather and climate with high rainfall followed by strong winds is very detrimental to farmers, because the growth of seaweed is disturbed, seaweed is broken, rope ties become detached and lost causing seaweed production to be not optimal.

The Effect of the Application of Harvest and Post-Harvest Agribusiness Sub-system (X3) on the Amount of Seaweed Production (Y). The analysis results in Table 2, harvest and post-harvest system variables $(\mathrm{X} 3)$ significantly affect the amount of seaweed production $(\mathrm{Y})$. 
The Harvest and Post-Harvest variables (X3) have a significance value | $p$ | 0,0000 smaller than 0,05 .

In harvesting and post-harvest agribusiness system, there are two significant variables: seaweed harvesting age and seaweed carrying technology or tools. The age of seaweed harvest affects the amount of seaweed production that will be produced. Seaweed farmers in Pahunga Lodu Subdistrict, East Sumba Regency harvested the seaweed when it aged about 40 days to 45 days. The result of this study are similar with the research conducted by Aluman, et al, (2016), which states that harvest age has a positive and significant influence on the amount of seaweed production in Bulagi District.

Seaweed drying technology or tools affect the number of quality products that can be sold in the market. The results of this study are in line with the research conducted by Pandelaki (2012). The process of carrying out the seaweed using tarpaulin, soil and sand is a deficient way to carry out the seaweed, thus it can reduce the quality of seaweed in Bantaeng Regency. The results of research conducted by Anggadireja et. al (2009) states that the quality of seaweed products is strongly influenced by the age of seaweed, weather conditions at harvest, how to harvest and drying methods. With high quality seaweed, farmers will easily get buyers and relatively high selling prices.

The Effect of Marketing Agribusiness Sub-system Application (X4) on Seaweed Farmers' Income (Z). The results of the analysis in Table 2 show that the variable marketing agribusiness system (X4) has a significant effect on the income of seaweed farmers (Z). The marketing agribusiness system variable (X4) has a significance value of $|p| 0.0000$, which is smaller than 0.05. This means that $\mathrm{Ha}$ is accepted and $\mathrm{Ho}$ is rejected, thus the hypothesis which argues that there is an influence of the marketing agribusiness system to the seaweed farmers' income are proven. The results show that the better the level of application in the marketing sub-system, the higher the income obtained.

In marketing agribusiness, there are 2 important variables: the place of sale or buyer of seaweed and the price of seaweed, which has a link between the two variables and affect the income earned by farmers. The result of this study is parallel with the research result conducted by Wuryaningsing, et al, (2014), which states that the dependence of farmers by selling dry seaweed to a collector or middleman in Pahawang Island and lack of consumer interest in seaweed, causing farmers' small income and prevent the success of seaweed cultivation. The result conducted by Arvianti (2014), stated that the process of bargaining always occurs between farmers and middlemen, but generally seaweed farmers in Wuakerong Village are always in a diffilcult position because eventually the middlemen take the role to determine the prices.

The Effect of the Amount of Seaweed Production (Y) on Seaweed Farmers' Income (Z). The result of analysis in Table 2 shows that the Amount of Seaweed Production variable $(Y)$ has a significant effect on the income of seaweed farmers (Z). It has a significance value of $|p| 0.0000$ which is smaller than 0.05 . The higher amount of seaweed produced will be directly proportional to the amount of income that will be obtained by the farmers. The results above are parallel with the results of research conducted by Wuryaningsing, et al, (2014), which states that the amount of production significantly influences the income of seaweed farmers in North Maluku. The results of this study are also supported by the results of Budiman et. Al (2011) which argues that the amount of production and selling value at reasonable prices affects the amount of income that will be obtained by the family of seaweed farmers.

\section{CONCLUSION}

The application of agribusiness systems in seaweed farming in Pahunga Lodu District, East Sumba Regency is divided into 4 sub-systems: upstream agribusiness sub-system, on farm sub-system, harvest and post-harvest agribusiness sub-system, and marketing agribusiness sub-system. In the upstream agribusiness system, or the provision of production facilities, seaweed farmers have been able to apply it very well with an index value of 86.8. In the on farm agribusiness sub-system, seaweed farmers are also able to 
apply it well with an index value of 86.2. In the harvest and post-harvest agribusiness subsystem, the index value is 89,85 which indicates that the farmers are able to apply the system very well. Meanwhile, in the marketing agribusiness sub-system, the application is categorized in a bad level, with an index value of 49.25 .

The variables of upstream agribusiness sub-system significantly affect the amount of production and income of seaweed farmers with a significance value of [p] of 0.0006 . Meanwhile, the on farm sub-system variables do not have a significant effect on the amount of production and income of seaweed farmers with a significance value of [p] of 0.0772 . The variables of harvest and post-harvest, as well as marketing agribusiness sub-system, significantly affect on the amount of production and income of seaweed farmers with both significance value of [p] of 0.0000 . Then, the variables of the amount of production have significant effect on the income of seaweed farmers with a significance value of [p] of 0.0000 .

\section{REFERENCES}

1. Akbar, A. F. (2014). Analisis Tingkat Produksi Rumput Laut di Kabupaten Jeneponto. Jurnal Galung Tropika, 2 (2): 60-73.

2. Anggadiredja Jana T., Achmad Zatnika., Heri Purwoto., dan Sri Istini. 2009. Rumput Laut. Jakarta: Penebar Swadaya.

3. Asriany. (2014). Analisis Usahatani Rumput Laut di Kecamatan Mandale, Kabupaten Pangkep. Jurnal Galung Tropika, 3 (3): 132-138.

4. Arvianti, E.Y., Sa'diyah, A. A., dan Dasion, P. R. K. (2014). Analisis Pemasaran Rumput Laut (Eucheuma SP) Di Desa Wuakerong, Kecamatan Nagawutung, Kabupaten Lembata. Jurnal Buana Sains, 14 (1): 1-10.

5. Aluman, O. D., Hadayani., dan Effendy. (2016). Analisis Produksi dan Pendapatan Rumput laut Di Desa Bulagi Dua, Kecamatan Bulagi, Kabupaten Banggai Kepulauan. Jurnal J. Agroland, 23 (2): 131-140.

6. Budiman, Aisyah, dan Harifuddin. (2011). Analisis Margin dan Efisiensi Pemasaran Rumput laut di Desa Mandale, Kabupaten Pangkep. Jurnal Agribisnis, 10 (3): 38-48.

7. Dinas Kelautan dan Perikanan Kabupaten Sumba Timur. 2016. Jumlah Produksi Rumput Laut Kabupaten Sumba Timur. Waingapu

8. Direktorat Jendral Perikanan Budidaya, Kementrian Kelautan dan Perikanan. 2005. Profil Rumput Laut Indonesia. Jakarta

9. Hasiru, R., Idris, Y. Niode., Erman, R., Bobby, R.Payu., dan Femmy, S. (2010). Study Kelayakan Klaster Rumput Laut Di Kabupaten Gorontalo Utara, Provinsi Gorontalo. Jurnal Inovasi Gorontalo, 5 (3): 7-15.

10. Saragih, B. 2007. Agribisnis Paradigma Baru Pertanian. Agrina. Yayasan Mulia Persada: Indonesia

11. Soekartawi, 2002. Prinsip Dasar Ekonomi Pertanian: Teori dan Aplikasi, Edisi Kedua, Cetakan Keempat. Jakarta: PT. Raja Grafindo Persada.

12. Sulaeman. 2006. Pengembangan Agribisnis Komoditi Rumput Laut Melalui Model Klaster Bisnis. Infokop Nomor 20 Tahun XXII, 2 (1): 56-63

13. Pandelaki, L. (2012). Strategi Pengembangan Budidaya Rumput Laut di Pulau Naik Kabupaten Minahasa Utara. Jurnal Perikanan dan Kelautan tropis, 8 (2): 52-56.

14. Wantaran AS dan Tamrin. (2012). Analisis Kelayakan Lokasi Budidaya Rumput Laut Di Perairan Teluk Dodinga, Kabupaten Halmahera Barat. Jurnal Perikanan dan Kelautan Tropis, 8 (1): 23-27.

15. Wuryaningsih, D. S., Dede Putri., dan Novi Rosanti. (2014). Analisis Pendapatan dan Strategi Pengembangan Budidaya Rumput Laut di Pulau Pahawang, Kecamatan Punduh Pidada, Kabupaten Pesawaran. Jurnal JIIA, 2 (1):56-63. 